\title{
3 Research Square

\section{Taxonomic and denitrifying bacteria communities associated with the interception of nitrate leaching by carbon amendment in the subsoil}

\section{Chen Chen}

China Agricultural University

Hui Han

China Agricultural University

Ya Meng

China Agricultural University

Hangyu Wu

China Agricultural University

Rui Jia

China Agricultural University

\section{Ting Xu}

China Agricultural University

guo-chun Ding ( $\nabla$ gc_ding@cau.edu.cn )

China agriculture university https://orcid.org/0000-0002-5468-5979

Ji Li

China Agricultural University

\section{Research}

Keywords: Carbon amendment, subsoil zone, nitrate leaching, denitrifying bacteria, bacterial diversity

Posted Date: January 16th, 2020

DOI: https://doi.org/10.21203/rs.2.20232/v2

License: (1) (1) This work is licensed under a Creative Commons Attribution 4.0 International License.

Read Full License 
The authors have withdrawn this preprint from Research Square 